\title{
Positive effect of taurine on preimplantation development of mouse embryos in vitro
}

\author{
J. C. M. Dumoulin ${ }^{1}$, J. L. H. Evers ${ }^{1}$, M. Bras ${ }^{1}$, M. H. E. C. Pieters ${ }^{2}$ and \\ J. P. M. Geraedts ${ }^{2}$ \\ ${ }^{1}$ Department of Obstetrics and Gynaecology, Academic Hospital Maastricht, University of \\ Limburg, Maastricht, The Netherlands; and ${ }^{2}$ Department of Genetics and Cell Biology, University \\ of Limburg, Maastricht, The Netherlands
}

\begin{abstract}
Summary. The effect of various taurine concentrations in modified Tyrode's medium on in vitro fertilization of mouse oocytes was examined. No significant difference in fertilization rate was found at concentrations of $0,0 \cdot 1,1,5,10$ and $20 \mathrm{~mm}$ taurine. In a second series of experiments, the effect of taurine on preimplantation embryonic development after fertilization in vitro was studied. At concentrations of 1, 5, 10 and $20 \mathrm{~mm}$ taurine, significantly more two-cell embryos reached the blastocyst stage compared with medium without taurine. Culture in the presence of $5 \mathrm{~mm}$ or $10 \mathrm{~mm}$ taurine resulted in blastocysts with the highest mean number of cells. The positive effect of taurine on embryonic development was found to be more pronounced both in a second medium (human tubal fluid medium) which has a higher potassium concentration than Tyrode's medium, and in a modified Tyrode's medium with an increased potassium concentration. In addition to these in vitro studies, it is reported that taurine comprised about $59 \%$ of the total free amino acid content in mouse oviduct flushings, compared with $17 \%$ in mouse serum.
\end{abstract}

Keywords: taurine; in vitro fertilization; embryonic development; mouse

\section{Introduction}

Taurine and its precursor hypotaurine are sulfur-containing $\beta$-amino acids, and they are present at relatively high concentrations in female reproductive tract fluids of several mammals (Meizel et al., 1980; Casslén, 1987; Miller \& Schultz, 1987), in human semen (Hernvann et al., 1986) and in spermatozoal acrosomes (Velázquez et al., 1986).

Much is already known about the role of taurine in the processes of sperm capacitation and in vitro fertilization (IVF) for different species. Hamster spermatozoa require taurine or hypotaurine in the culture medium to maintain their motility and viability during in vitro capacitation (Mrsny et al., 1979). Also, the fertilizing capacity of hamster spermatozoa in vitro is enhanced by taurine and hypotaurine (Leibfried \& Bavister, 1981, 1982). In the cow, the presence of hypotaurine in the medium stimulates in vitro fertilization (Ball et al., 1983). However, mouse spermatozoa do not need the addition of taurine to exhibit their full fertilizing ability (Fraser, 1986). Although it has been reported that human spermatozoa capacitate faster in medium with taurine added (Mortimer, 1986; Chan, 1985), their fertilizing ability in vitro does not seem to be increased by taurine (Mahadevan \& Trounson, 1985).

However, the role of taurine in mammalian embryonic development during the preimplantation stages is less clear. The purpose of the present study was first to examine the effect of taurine on in vitro culture of preimplantation mouse embryos. Second, reproductive tract fluids of female mice were analysed for the presence of taurine. 


\section{Materials and Methods}

Modified Tyrode's medium (T6) (Quinn et al., 1984) was used as culture medium. For in vitro fertilization, the medium was supplemented with $30 \mathrm{mg}$ Fraction V bovine serum albumin/ml (BSA, Sigma No. A7906, St Louis, MO, USA); $5 \mathrm{mg} \mathrm{BSA} / \mathrm{ml}$ was used for the embryo culture. Media with different taurine concentrations were prepared by mixing a stock solution of $20 \mathrm{~mm}$ taurine in culture medium (Sigma, No. T7146) with medium without taurine. The osmolality of all media was adjusted to $280-285 \mathrm{mOs} / \mathrm{kg}$ before use, the $\mathrm{pH}$ was 7.5 after equilibration in an atmosphere of $5 \% \mathrm{CO}_{2}$ in air.

For all experiments $(\mathrm{C} 57 \mathrm{BL} / 6 \times \mathrm{DBA} / 2) \mathrm{F}_{1}$ hybrid female mice $(\mathrm{B} 6 \mathrm{D} 2 \mathrm{~F} 1)$ were purchased from Charles River Wiga (Sulzfeld, Germany). Oocytes were obtained by superovulating 7-11-week-old females with $10 \mathrm{iu}$ pregnant mares' serum gonadotrophin (PMSG, Sigma) and $48 \mathrm{~h}$ later 10 iu human chorionic gonadotrophin (hCG, Sigma). Sixteen hours after hCG injection, the females were killed by cervical dislocation. Their oviducts were dissected and transferred to Hepes-buffered T6 (Quinn et al., 1984). The cumulus masses containing the oocytes were released from the swollen ampullae of the oviducts, washed once and transferred to Multidish 4-well dishes (Nunc, Life Technology BV, Breda, The Netherlands) containing $1 \mathrm{ml}$ of the fertilization medium.

Caudal epididymal spermatozoa were obtained from 12-18-week-old CD-1 males. After incision of the tissues, the spermatozoa were allowed to disperse into T6 medium supplemented with $30 \mathrm{mg}$ BSA $/ \mathrm{ml}$. After $30 \mathrm{~min}$, the epididymal tissue was removed and the spermatozoa were allowed to capacitate for a further $90 \mathrm{~min}$ at $37^{\circ} \mathrm{C}$. The oocytes were inseminated with a calculated amount of the sperm suspension to give a final concentration of approximately 2000000 motile sperm $/ \mathrm{ml}$.

Experiments to study the effect of taurine on fertilization and embryonic development in vitro were of a randomized block design (Fleiss, 1986). Oocytes from different females were not pooled, but were inseminated separately. The embryos from each female were distributed over a set of the different experimental media and were not pooled with embryos from other females. In this way, the comparison between different experimental media is repeated in every female used. To obtain at least five oocytes in every experimental medium from each female, only oocytes from females who produced $>30$ oocytes were used.

Twenty-four hours after insemination, normal-appearing two-cell embryos, which were considered fertilized, were counted. At $120 \mathrm{~h}$ after insemination, the numbers of blastocysts were assessed. The percentages of embryos completing preimplantation development were calculated on the basis of the fertilization rate. The mean percentages \pm standard error of the mean (SEM) of fertilization (number of two-cell embryos:number of oocytes) and of embryonic development (number of blastocysts: number of two-cell embryos) per female were calculated for every experimental group. Statistical analysis of the data was performed using an analysis of variance (ANOVA). When treatment effects were significant, multiple-comparison tests were used to determine which treatment means were different (Fleiss, 1986). In Expts 1 and 2, in which comparisons were made between groups cultured in the presence of several taurine concentrations and a control group cultured without taurine, Dunnett's procedure was used. In Expts 3 and 4 , in which only a few comparisons between the group means were of interest, the Bonferroni criterion was used.

\section{Experiment 1: dose-response of fertilization in vitro to taurine}

Four replicate experiments using four to six females per experiment were performed. A sperm suspension from four males was divided among insemination media containing taurine in six different concentrations $(0,0 \cdot 1,1,5,10$ and $20 \mathrm{~mm}$ ) and capacitated for a further $90 \mathrm{~min}$. Oocytes were freed from cumulus cells using hyaluronidase, and divided per female among the six insemination media. Five hours after insemination, oocytes of each experimental group were rinsed once and transferred to medium without taurine.

\section{Experiment 2: dose-response of embryonic development to taurine}

Five replicate experiments using five to nine females per experiment were performed. Media with the same taurine concentrations as in Expt 1 were used. Five hours after insemination in medium without taurine, oocytes were divided at random among medium without taurine and the five taurine-containing media. All the embryos, from two experiments, developing a distinct blastocoel at $120 \mathrm{~h}$ after insemination were fixed and stained with $4^{\prime} 6$-diamidino-2phenylindole (DAPI) according to the method of Mori et al. (1988). This DNA-staining technique allows an accurate count of the number of nuclei, and thus of the number of cells in each embryo.

\section{Experiment 3: comparison of two culture media of different inorganic composition supplemented with taurine}

In this experiment, T6 medium and human tubal fluid medium (HTF) (Quinn et al., 1985) were used for the culture of embryos. Four replicate experiments using four to six females per experiment were performed. Five hours after insemination in T6 medium without taurine, the oocytes were randomly divided among T6 and HTF medium without taurine and T6 and HTF medium with $5 \mathrm{~mm}$ taurine. 


\section{Experiment 4: comparison of T6 medium with two $\mathrm{K}^{+}$concentrations supplemented with taurine}

Three replicate experiments using four to six females per experiment were performed using standard T6 medium $\left(1.4 \mathrm{~mm} \mathrm{~K}^{+}\right)$and $\mathrm{T} 6$ with $5 \mathrm{~mm} \mathrm{~K} \mathrm{~K}^{+}$for the culture of embryos. Osmolality of the T6 with added $\mathrm{K}^{+}$was adjusted to $280 \mathrm{mOs} / \mathrm{kg}$ by replacing a small amount of medium by water. Five hours after insemination in T6 medium without taurine, the oocytes were randomly divided among $\mathrm{T} 6$ and $\mathrm{T} 6$ plus $5 \mathrm{~mm} \mathrm{~K}{ }^{+}$, both with, and without, $5 \mathrm{~mm}$ taurine.

\section{Experiment 5: the presence of taurine in mouse oviduct fluid}

Mice were induced to ovulate by injection of 3 iu PMSG and then 3 iu HCG, $48 \mathrm{~h}$ later. Oviduct flushings and serum were collected $40 \mathrm{~h}$ after hCG injection. After anaesthetizing the mice with ether, blood samples were collected by puncture of the retro-orbital plexus. The blood was allowed to clot and serum was separated from cells by centrifugation $(1200 \mathrm{~g}, 10 \mathrm{~min})$. The mice were killed by cervical dislocation, and both oviducts together with a small portion of the uterus near the uterotubal junction $(0.1-0.2 \mathrm{~mm})$ were dissected. After rinsing the oviducts in $5 \%$ dextrose (Sigma) and blotting them on filter paper to remove most of the adhering peritoneal fluids, they were transferred to a drop of $150 \mu \mathrm{l}$ dextrose solution. Part of this fluid was used to flush the oviducts using a plastic tuberculin syringe attached to a blunt hypodermic needle with an outer diameter of $0.21 \mathrm{~mm}$ (Hamilton N733, v. Oortmerssen, Den Haag. The Netherlands) introduced into the ampultar end of the oviduct. These manipulations were performed under a stereomicroscope. Flushings were completed within $10 \mathrm{~min}$ of death of the animal. The fluid used for flushing the oviducts was centrifuged at $2000 \mathrm{~g}$ for $10 \mathrm{~min}$ to remove any cellular debris and the supernatant was stored at $-20^{\circ} \mathrm{C}$.

Amino acid analysis was performed with an amino acid analyser (LKB/Biochrom model 4151, Cambridge, UK) according to the method of Blom \& Huijmans (1985) using norleucine as an internal standard.

\section{Results}

\section{Experiment 1: dose-response of fertilization in vitro to taurine}

From 20 females, 779 oocytes were obtained (mean number of oocytes \pm standard deviation (SD) per female: $39 \cdot 0 \pm 5 \cdot 6$ ) and divided among the six media. No significant differences were observed between the number of two-cell embryos, counted at $24 \mathrm{~h}$ after insemination, in medium without taurine and the five media with different taurine concentrations (Table 1).

Table 1. Effect of taurine on the fertilization in vitro of mouse oocytes

\begin{tabular}{ccc}
\hline $\begin{array}{c}\text { Taurine } \\
(\mathrm{mM})\end{array}$ & $\begin{array}{c}\text { Two-cell } \\
\text { formation }(\%)^{*}\end{array}$ & $\begin{array}{c}\text { Mean } \\
\text { fertilization rate } \\
\text { per female } \pm \text { SEM } \dagger\end{array}$ \\
\hline 0 & $85: 133(64)$ & $0.64 \pm 0.05$ \\
$0 \cdot 1$ & $79: 126(63)$ & $0.62 \pm 0.06$ \\
$1 \cdot 0$ & $82: 132(62)$ & $0 \cdot 62 \pm 0.05$ \\
$5 \cdot 0$ & $83: 130(64)$ & $0.64 \pm 0.04$ \\
$10 \cdot 0$ & $85: 131(65)$ & $0.65 \pm 0.06$ \\
$20 \cdot 0$ & $74: 127(58)$ & $0 \cdot 59 \pm 0.06$ \\
\hline
\end{tabular}

*Total number of two-cell embryos:total number of oocytes.

$\dagger$ Means and SEM are based on 20 replicates: the oocytes of each of 20 females were divided among the six media with different taurine concentrations, inseminated and cultured to the two-cell stage separately. ANOVA: not significant.

\section{Experiment 2: dose-response of embryonic development to taurine}

For these experiments, 34 females were used. Five hours after insemination in medium without taurine, a mean number of $42 \cdot 7 \pm 10.5$ oocytes per female (total number of oocytes: 1451) was divided among the six media. After $24 \mathrm{~h}$, the numbers of two-cell embryos were not significantly 
different in the six media (data not shown). Table 2 shows that, with respect to the mean number of blastocysts per female developing from two-cell embryos, the means of the groups cultured in media with taurine concentrations of $1-20 \mathrm{~mm}$ are significantly different from the mean of the control group (no taurine). The mean cell number of blastocysts, as estimated by the number of nuclei that developed in media with $5 \mathrm{~nm}$ and $10 \mathrm{~nm}$ taurine was significantly higher than in medium without taurine (Table 3).

Table 2. Effect of various taurine concentrations in the culture medium on the development of mouse embryos to the blastocyst stage

\begin{tabular}{ccc}
\hline $\begin{array}{c}\text { Taurine } \\
(\mathrm{mM})\end{array}$ & $\begin{array}{c}\text { Blastocyst } \\
\text { formation }(\%)^{*}\end{array}$ & $\begin{array}{c}\text { Mean } \\
\text { blastocyst formation } \\
\text { per female } \pm \text { SEM } \dagger\end{array}$ \\
\hline 0 & $99: 165(60)$ & $0.64 \pm 0.04$ \\
0.1 & $117: 173(68)$ & $0.70 \pm 0.04$ \\
1.0 & $131: 167(78)$ & $0.82 \pm 0.03 \S$ \\
5.0 & $121: 157(77)$ & $0.79 \pm 0.04 \S$ \\
10.0 & $117: 153(76)$ & $0.80 \pm 0.04 \S$ \\
20.0 & $130: 165(79)$ & $0.80 \pm 0.04 \S$ \\
\hline
\end{tabular}

*Total number of blastocysts:total number of two-cell embryos.

† Means and SEM are based on 34 replicates: after in vitro fertilization in medium without taurine, the oocytes of each of 34 females were divided among the six media with different taurine concentrations and cultured separately.

\$ANOVA: $P<0.01$, treatment means indicated are significantly different from the control group.

Table 3. Cell numbers of mouse blastocysts after development of the embryos in T6 media with various taurine concentrations

\begin{tabular}{ccc}
\hline $\begin{array}{c}\text { Taurine } \\
(\mathrm{mM})\end{array}$ & $\begin{array}{c}\text { Number of blastocysts } \\
\text { successfully analysed }\end{array}$ & $\begin{array}{c}\text { Number of cells } \\
\text { Mean } \pm \text { SEM }\end{array}$ \\
\hline 0 & 33 & $54 \cdot 7 \pm 4 \cdot 0$ \\
$0 \cdot 1$ & 41 & $62 \cdot 0 \pm 3 \cdot 5$ \\
$1 \cdot 0$ & 36 & $52 \cdot 6 \pm 3 \cdot 1$ \\
$5 \cdot 0$ & 42 & $67 \cdot 9 \pm 3 \cdot 4^{*}$ \\
$10 \cdot 0$ & 41 & $64 \cdot 8 \pm 3 \cdot 2^{*}$ \\
$20 \cdot 0$ & 26 & $58 \cdot 3 \pm 4 \cdot 1$ \\
\hline
\end{tabular}

*ANOVA: $P<0.05$, treatment means indicated are significantly different from the control group.

\section{Experiment 3: comparison of two culture media of different inorganic composition supplemented with taurine}

For these experiments, 18 females were used. Five hours after insemination in medium without taurine, a mean number of $41.3 \pm 8.4$ (SD) oocytes per female (total number of oocytes: 744) was divided among the two types of culture medium, with and without $5 \mathrm{~mm}$ taurine. This concentration of taurine was chosen because it resulted in blastocysts with the highest mean number of cells (Table 3). After $24 \mathrm{~h}$, the numbers of two-cell embryos were not significantly 
different in the four groups (data not shown). For both types of medium, embryo development in taurine-supplemented medium resulted in a significantly higher blastocyst formation (Table 4).

\section{Experiment 4: comparison of T6 medium with two $\mathrm{K}^{+}$concentrations supplemented with taurine}

For these experiments, 17 females were used. Five hours after insemination in medium without taurine, a mean number of $41.9 \pm 6.4$ (SD) oocytes per female (total number of oocytes: 712 ) was divided among the two $\mathrm{T} 6$ media with different $\mathrm{K}^{+}$concentrations, with and without $5 \mathrm{~mm}$ taurine. The numbers of two-cell embryos $24 \mathrm{~h}$ after insemination were not significantly different in the four groups (data not shown). Embryonic development in $\mathrm{T} 6$ with $5 \mathrm{mM} \mathrm{K}^{+}$without taurine was retarded (Table 5) as compared to $\mathrm{T} 6$ without extra potassium. For both $\mathrm{K}^{+}$concentrations, embryo development in taurine-supplemented medium resulted in a significantly higher blastocyst formation (Table 5).

Table 4. Effect of $5 \mathrm{~mm}$ taurine in two media of different inorganic composition on the development of mouse zygotes to the blastocyst stage

\begin{tabular}{lccc}
\hline Medium & $\begin{array}{c}\text { Taurine } \\
(\mathrm{mM})\end{array}$ & $\begin{array}{c}\text { Blastocyst } \\
\text { formation (\%)* }\end{array}$ & $\begin{array}{c}\text { Mean blastocyst formation } \\
\text { per female } \pm \text { SEM }{ }^{\dagger}\end{array}$ \\
\hline T6 & 0 & $80: 119(67)$ & $0.64 \pm 0.05$ \\
& 5 & $93: 116(80)$ & $0 \cdot 78 \pm 0.04 \S$ \\
HTF & 0 & $54: 123(44)$ & $0.43 \pm 0.05 \S$ \\
& 5 & $81: 118(69)$ & $0.70 \pm 0.04 \$$ \\
\hline
\end{tabular}

*Total number of blastocysts:total number of zygotes.

† Means and SEM are based on 18 replicates: the zygotes of each of 18 females were divided among the four media and cultured separately.

ANOVA: $P<0.001 ; \S$ significantly different from T6 medium without taurine; $\$$ tsignificantly different from HTF medium without taurine.

Table 5. Effect of $5 \mathrm{~mm}$ taurine in $\mathrm{T} 6$ media with different potassium levels on the development of mouse zygotes to the blastocyst stage

\begin{tabular}{ccrc}
\hline $\begin{array}{c}\text { Potassium } \\
(\mathrm{mM})\end{array}$ & $\begin{array}{c}\text { Taurine } \\
(\mathrm{mM})\end{array}$ & $\begin{array}{c}\text { Blastocyst } \\
\text { formation }(\%)^{*}\end{array}$ & $\begin{array}{c}\text { Mean blastocyst formation } \\
\text { per female } \pm \text { SEM }^{\dagger}\end{array}$ \\
\hline 1.4 & 0 & $86: 122(70)$ & $0.67 \pm 0.08$ \\
1.4 & 5.0 & $108: 129(84)$ & $0.84 \pm 0.04 \$$ \\
5.0 & 0 & $67: 124(54)$ & $0.51 \pm 0.06 \$$ \\
5.0 & 5.0 & $91: 122(75)$ & $0.74 \pm 0.04 \ddagger$ \\
\hline
\end{tabular}

*Total number of blastocysts:total number of zygotes.

†Means and SEM are based on 17 replicates: the zygotes of each of 17 females are divided among the four media and cultured separately. ANOVA: $P<0.001 ; \S$ significantly different from the mean blastocyst formation in T6 medium without taurine; \$significantly different from T6 medium with extra $\mathrm{K}^{+}$and without taurine.

\section{Experiment 5: the presence of taurine in mouse oviduct fluid}

Collection of nonhaemolysed serum and oviduct-flushing fluid was successful in five mice. In the $150 \mu \mathrm{l}$ fluid with which both oviducts of one mouse were flushed, a total mean concentration of $558 \pm 121 \mu \mathrm{mol} / \mathrm{l}$ free amino acids was found. The mean concentration of taurine in the oviductflushing samples was $329 \pm 70 \mu \mathrm{mol} / 1$ ( $\pm \mathrm{SD}$ ). As oviduct fluid volume measurements were not 
Table 6. Amino acid concentration and composition in serum and oviduct flushing fluid in mice

\begin{tabular}{|c|c|c|c|}
\hline \multirow{3}{*}{$\frac{\text { Amino acid }}{\text { Taurine }}$} & \multirow{2}{*}{$\begin{array}{c}\text { Concentration } \\
\text { in serum } \\
\text { Mean } \mu \mathrm{mol} / 1 \pm \mathrm{SD}\end{array}$} & \multicolumn{2}{|c|}{ Composition } \\
\hline & & \multicolumn{2}{|c|}{$\begin{array}{l}\text { Serum Oviduct flushings } \\
(\% \text { of total } \pm \text { SEM })^{*}\end{array}$} \\
\hline & $590 \pm 204$ & 17 & $59+1$ \\
\hline Aspartic acid & $18 \pm \quad 7$ & $<1$ & $\overline{4}$ \\
\hline Threonine & $151 \pm$ & 4 & 1 \\
\hline Serine & $169 \pm$ & 4 & 2 \\
\hline Glutamic acid & $42 \pm \quad 16$ & 1 & 9 \\
\hline Glutamine & $766 \pm 309$ & $21 \pm 1$ & 5 \\
\hline Proline & $79 \pm \quad 29$ & & \\
\hline Glycine & $437 \pm \quad 173$ & 12 & 10 \\
\hline Alanine & $428 \pm 136$ & $12 \pm 1$ & 5 \\
\hline Valine & $227 \pm \quad 79$ & $\overline{6}$ & 1 \\
\hline Methionine & $66 \pm$ & & \\
\hline Isoleucine & $112 \pm$ & 3 & 1 \\
\hline Leucine & $163 \pm$ & 5 & 1 \\
\hline Tyrosine & $63 \pm$ & & \\
\hline Phenylalanine & $74 \pm$ & 2 & 1 \\
\hline Ornithine & $52 \pm \quad 21$ & & \\
\hline Lysine & $389 \pm 153$ & $11 \pm 1$ & 1 \\
\hline Histidine & $54 \pm \quad 19$ & & \\
\hline Arginine & $176 \pm \quad 61$ & & \\
\hline Total & $4055 \pm 145 I$ & & \\
\hline
\end{tabular}

*The percentage of the total amino acid content measured (only amino acids that were found both in serum and in oviduct flushings are taken into account); SEM are not shown when they are below $0.5 \%$.

made, only the relative composition (\%) of amino acids found in the oviduct flushings is tabulated in Table 6, together with the relative composition of the same amino acids found in serum. Amino acids found in serum that could not be demonstrated in the oviduct flush samples were not taken into account. Although amino acid concentrations varied considerably among mice (e.g. minimum-maximum values of taurine concentration in serum and oviduct flushings of the five mice are $373-912 \mu \mathrm{mol} / 1$ and $233-401 \mu \mathrm{mol} / 1$, respectively), the variation in amino acid composition was very small, both in serum and in oviduct flushings.

\section{Discussion}

The results indicate that capacitation and IVF in the presence of taurine do not affect fertilization rate in mice at any of the concentrations tested. This is consistent with the observations of Fraser (1986), who reported that mouse spermatozoa do not require taurine to exhibit their maximum fertilizing ability and showed that, although addition of $0.1,0.3$ or $1.0 \mathrm{~mm}$ taurine in the absence of BSA resulted in higher fertilization rates, this increase was not found in media supplemented with BSA.

The inclusion of taurine in the culture medium resulted in significantly more two-cell embryos reaching the blastocyst stage for all tested taurine concentrations of $1 \mathrm{~mm}$ and higher. Embryos cultured in the presence of 5 and $10 \mathrm{~mm}$ taurine resulted in blastocysts with a higher mean number of cells compared with blastocysts cultured in medium without taurine.

To test whether the observed positive effect of taurine was a phenomenon specific for T6 culture medium, we compared the development of mouse embryos in T6 medium and HTF medium, with and without taurine. In the HTF medium, the positive effect of taurine was even more pronounced 
than in T6 medium. HTF has been shown by Quinn et al. (1985) to be a more suitable medium than T6 for human IVF and for culturing mouse one-cell embryos. Contrary to the findings of Quinn et al., comparing T6 and HTF without taurine, significantly fewer blastocysts developed in HTF medium than in T6 medium. Quinn et al. postulated that the high $\mathrm{K}^{+}$level $(5.06 \mathrm{mM})$ in HTF medium compared with the $\mathrm{K}^{+}$level $(1.42 \mathrm{mM})$ in $\mathrm{T} 6$ is responsible for the better results in the HTF medium. However, our results agree with the results of Wiley et al. (1986), who found that more blastocysts developed in $\mathrm{T} 6$ medium with $1.4 \mathrm{mM} \mathrm{K}^{+}$than in $\mathrm{T} 6$ with $6.0 \mathrm{mM} \mathrm{K} \mathrm{K}^{+}$.

Results from our investigation of the interactive effect between taurine and $\mathrm{K}^{+}$on the development of mouse embryos in $\mathrm{T} 6$ medium with the standard $\mathrm{K}^{+}$concentration and $\mathrm{T} 6$ medium with an increased $(5.0 \mathrm{mM}) \mathrm{K}^{+}$concentration, both with and without taurine, also demonstrate that $\mathrm{K}^{+}$, and not some other component of the HTF medium, is responsible for the differences in embryonic development in T6 and HTF medium.

Taurine and $\mathrm{K}^{+}$are known to interact in sperm capacitation and fertilization processes (Meizel, 1985). Although their exact roles are not clear, both compounds seem to exert their effect by influencing the activity of the enzyme $\mathrm{Na}^{+}-\mathrm{K}^{+}$-ATPase. $\mathrm{Na}^{+}-\mathrm{K}^{+}$-ATPase is a plasma-membrane enzyme that controls intracellular $\mathrm{K}^{+}$levels. The activity of this enzyme is inhibited in a low $\mathrm{K}^{+}$-environment (Thomas, 1972). Mrsny and Meizel (1985) showed that taurine decreases the $\mathrm{Na}^{+}-\mathrm{K}^{+}$-ATPase activity of sperm cell membranes in a dose-dependent manner. High $\mathrm{K}^{+}$levels have been shown to be detrimental to sperm motility in vitro (Fraser, 1983). Studies by Meizel et al. (1980) have shown that, in the presence of $3.1 \mathrm{mM} \mathrm{K}^{+}$, addition of $0.5 \mathrm{~mm}$ taurine is needed to preserve hamster sperm motility during in vitro capacitation. In medium with a very low $\mathrm{K}^{+}$ concentration, the addition of taurine is not needed (Mrsny \& Meizel, 1985). It has been suggested that taurine may protect the spermatozoa against high $\mathrm{K}^{+}$concentrations by reducing the $\mathrm{Na}^{+}-\mathrm{K}^{+}$-A TPase activity and consequently the influx of extracellular $\mathrm{K}^{+}$(Mrsny \& Meizel, 1985).

Both taurine and $\mathrm{K}^{+}$are present in high concentrations in mammalian reproductive tract fluids. We found in the mouse that taurine comprised about $17 \%$ of the total free amino acid content in serum, whereas it amounted to $59 \%$ in the oviduct flushing samples. The relative proportions of the amino acids found in serum are comparable to those found by Schultz et al. (1981). Human uterine fluid has also been shown to contain high concentrations of taurine, varying from 3 to $17 \mathrm{mmol} / \mathrm{l}$, i.e. up to 400 -fold higher than that in blood plasma (Casslén, 1987). The concentration of taurine is highest during the luteal phase of the menstrual cycle (Casslén, 1987). The $\mathrm{K}^{+}$concentration in human uterine fluid has been shown to be approximately $20 \mathrm{~mm}$ at midcycle, which is about five times higher than that in human plasma (Casslén, 1984). Different $\mathrm{K}^{+}$ concentrations in the human oviduct have been reported. Lippes et al. (1972) found $\mathrm{K}^{+}$concentrations between $7.7 \mathrm{~mm}$ and $9.9 \mathrm{~mm}$, depending on the stage of the menstrual cycle, whereas Borland et al. (1980) found a mean concentration of $21 \mathrm{mM} \mathrm{K}^{+}$. In the mouse, the $\mathrm{K}^{+}$ concentration in oviduct fluid was found to vary from $18 \mathrm{~mm}$ to $30 \mathrm{~mm}$, depending on the stage of the oestrous cycle and the segment of the oviduct studied (Borland et al., 1977; Roblero et al., 1976). During pseudopregnancy, mouse uterine fluid has a very high $\mathrm{K}^{+}$content, ranging from $35 \mathrm{~mm}$ on day 1 to $75 \mathrm{~mm}$ on day 5 (Wales \& Edirisinghe, 1989).

The high combined concentration of taurine and $\mathrm{K}^{+}$in reproductive tract fluids suggests that, in vivo, taurine might also protect the spermatozoa from the high $\mathrm{K}^{+}$levels by reducing the $\mathrm{Na}^{+}-\mathrm{K}^{+}$-ATPase activity (Mrsny \& Meizel, 1985). Not only do mammalian sperm capacitation and fertilization take place in uterine and oviductal fluids, but these fluids also make up the environment in which the embryo develops during the preimplantation stages. It is possible that taurine influences embryonic development in the same manner as it influences sperm motility, capacitation and fertilization, i.e. by protection against the high $\mathrm{K}^{+}$concentrations found in reproductive tract fluids. Findings of a greater stimulating effect of taurine in the media containing higher $\mathrm{K}^{+}$concentration are consistent with such a hypothesis. It remains to be shown whether the favourable role of taurine in embryonic development is exerted by protecting embryos against high $\mathrm{K}^{+}$concentrations by decreasing the $\mathrm{Na}^{+}-\mathrm{K}^{+}$-ATPase activity of embryonic membranes. 
We thank J. A. Land for helpful discussions concerning this manuscript and J. A. Bakker for the amino acid analysis.

\section{References}

Ball, G.D., Leibfried, M.L., Lenz, R.W., Ax, R.L., Bavister, B.D. \& First, N.L. (1983) Factors affecting successful in vitro fertilization of bovine follicular oocytes. Biol. Reprod. 28, 717-725.

Blom, W. \& Huijmans, J. (1985) Differential diagnosis of (inherited) amino-acid metabolism or transport disorders. Science Tools 32, 10--22.

Borland, R.M., Hazra, S., Biggers, J.D. \& Lechene, C.P. (1977) The elemental composition of the environments of the gametes and preimplantation embryo during initiation of pregnancy. Biol. Reprod. 16, $147-157$.

Borland, R.M., Biggers, J.D., Lechene, C.P. \& Taymor, M.L. (1980) Elemental composition of fluid in the human Fallopian tube. J. Reprod. Fert. 58, 479-482.

Casslén, B. \& Nilsson, B. (1984) Human uterine fluid, examined in undiluted samples for osmolarity and the concentrations of inorganic ions, albumin, glucose, and urea. Am. J. Obstet. Gynecol. 150, 877-881.

Casslén, B.G. (1987) Free amino acids in human uterine fluid. J. Reprod. Med. 32, 181-184.

Chan, S.Y.W. (1985) Taurine and human spermatozoal capacitation. Cell Biol. Intern. Rep. 9, 127-130.

Fleiss, J.L. (1986) The Design and Analysis of Clinical Experiments. Wiley \& Sons, New York.

Fraser, L.R. (1983) Potassium ions modulate expression of mouse sperm fertilizing ability, acrosome reaction and hyperactivated motility in vitro. J. Reprod. Fert. 69, 539-553.

Fraser, L.R. (1986) Both taurine and albumin support mouse sperm motility and fertilizing ability in vitro but there is no obligatory requirement for taurine. $J$. Reprod. Fert. 77, 271-280.

Hernvann, A., Gonzales, J., Troupel, S. \& Galli, A. (1986) Amino acid content of human semen in normal and infertility cases. Andrologia 18, 461-469.

Leibfried, M.L. \& Bavister, B.D. (1981) The effects of taurine and hypotaurine on in vitro fertilization in the golden hamster. Biol. Reprod. 4, 57-63.

Leibfried, M.L. \& Bavister, B.D. (1982) Effects of epinephrine and hypotaurine on in-vitro fertilization in the golden hamster. J. Reprod. Fert. 66, 87-93.

Lippes, J., Enders, R.G., Pragay, D.A. \& Bartholomew, W.R. (1972) The collection and analysis of human Fallopian tubal fluid. Contraception 5, 85-94.

Mahadevan, M.M. \& Trounson, A.O. (1985) Removal of the cumulus oophorus from the human oocyte for in vitro fertilization. Fert. Steril. 43, 263-267.

Meizel, S. (1985) Molecules that initiate or help stimulate the acrosome reaction by their interaction with the mammalian sperm surface. Am. J. Anat. 174, 285-302.

Meizel, S., Lui, C.W., Working, P.K. \& Mrsny, R.J. (1980) Taurine and hypotaurine: their effects on motility, capacitation and the acrosome reaction of hamster sperm in vitro and their presence in sperm and reproductive tract fluids of several mammals. Develop., Growth and Differ. 22, 483-494.

Miller, J.G.O. \& Schultz, G.A. (1987) Amino acid content of preimplantation rabbit embryos and fluids of the reproductive tract. Biol. Reprod. 36, 125-129.

Mori, C., Hashimoto, H. \& Hoshino, K. (1988) Fluorescence microscopy of nuclear DNA in oocytes and zygotes during in vitro fertilization and development of early embryos in mice. Biol. Reprod. 39, 737-742.

Mortimer, D. (1986) Elaboration of a new culture medium for physiological studies on human sperm motility and capacitation. Human Reprod. 1, 247-250.

Mrsny, R.J., Waxman, L. \& Meizel, S. (1979) Taurine maintains and stimulates motility of hamster sperm during capacitation in vitro. J. Exp. Zool. 210 , $123-128$.

Mrsny, R.J. \& Meizel, S. (1985) Inhibition of hamster sperm $\mathrm{Na}^{+}, \mathrm{K}^{+}$-ATPase activity by taurine and hypotaurine. Life Sci. 36, 271-275.

Quinn, P., Warnes, G.M., Kerin, J.F. \& Kirby, C. (1984) Culture factors in relation to the success of human in vitro fertilization and embryo transfer. Fert. Steril. 41, 202-209.

Quinn, P., Kerin, J.F. \& Warnes, G.M. (1985) Improved pregnancy rate in human in vitro fertilization with the use of a medium based on the composition of human tubal fluid. Fert. Steril. 44, 493-498.

Roblero, L., Biggers, J.D. \& Lechene, C.P. (1976) Electron probe analysis of the elemental microenvironment of oviducal mouse embryos. $J$. Reprod. Fert. 46, 431-434.

Schultz, G.A., Kaye, P.L., McKay, D.J. \& Johnson, M.H. (1981) Endogenous amino acid pool sizes in mouse eggs and preimplantation embryos. J. Reprod. Fert. 61, 387-393.

Thomas, R.C. (1972) Electrogenic sodium pump in nerve and muscle cells. Physiol. Rev. 52, 563-594.

Velázquez, A., Delgado, N.M. \& Rosado, A. (1986) Taurine content and amino acid composition of human acrosome. Life Sci. 38, 991-995.

Wales, R.G. \& Edirisinghe, W.R. (1989) Volume of fluid and concentration of cation and energy substrates in the uteri of mice during early pseudopregnancy. Reprod. Fertil. Dev. 1, 171-178.

Wiley, L.M., Yamami, S. \& Van Muyden, D. (1986) Effect of potassium concentration, type of protein supplement, and embryo density on mouse preimplantation development in vitro. Fert. Steril. 45, $111-119$. 